\title{
Bioconversion of duck blood cell: process optimization of hydrolytic conditions and peptide hydrolysate characterization
}

\author{
Zhaojun Zheng ${ }^{1}$, Xubiao Wei ${ }^{1}$, Tingting Shang ${ }^{1}$, Yan Huang ${ }^{2}$, Cong Hu ${ }^{1}$ and Rijun Zhang ${ }^{*}$
}

\begin{abstract}
Background: As the protein-laden by-product, red blood cells (RBCs) from poultry blood is a potential source of protein used as food and feed ingredient. However, RBC was currently underutilized. Therefore, it is an urgent need to develop feasible and cost-effective methods for converting poultry waste into nutritional and functional products.

Results: To take full advantage of this poultry waste, peptide hydrolysate was produced by deep controllable bioconversion of RBC, by means of synergistic combination of neutrase and flavourzyme. In this work, the functional properties and antioxidant activity of peptide hydrolysate were also characterized. The degree of hydrolysis (DH) was optimized using response surface methodology, and optimal hydrolysis conditions were found to be: temperature $51^{\circ}$ C, substrate concentration $14 \%(\mathrm{~W} / \mathrm{V})$, initial pH 7.0, and time $7.5 \mathrm{~h}$. The red blood cell hydrolysate (RBCH) obtained not only possessed plentiful small peptides $(<3 \mathrm{kDa}, 68.14 \%)$, but also was abundant in essential amino acids, accounting for over $50 \%$ of total amino acids. In addition to its excellent solubility $(>80 \%)$, emulsifying and foaming properties, RBCH also exhibited notable antioxidant activities, such as DPPH (2,2-diphenyl- 1-picrylhydrazyl) radical-scavenging activity $\left({ }^{\left(C_{50}\right.}\right.$, $4.16 \mathrm{mg} / \mathrm{mL}$ ), reducing power, metal chelating ability and inhibiting lipid peroxidation.
\end{abstract}

Conclusions: $\mathrm{RBCH}$ enriched in small peptides has the potential to be a new food additive with outstanding functional and antioxidant properties, and a process was established for converting poultry waste into peptide hydrolysate using neutrase and flavourzyme.

Keywords: Antioxidant activity, Degree of hydrolysis, Functional properties, Peptide hydrolysate, Response surface methodology

\section{Background}

In recent years, recycling of wastes from agricultural and food processing has been regarded as a significant industrial procedure to alleviate the shortage of protein resource. Animal blood derived from slaughterhouse waste is a potential edible protein source for human consumption [1]. Red blood cell (RBC), the major fraction of blood, accounts for about $60 \%$ of the total protein content, which is currently underutilized and discarded [2]. Therefore, finding ways to utilize RBC is necessary for maximizing the economical benefits and reducing the problems associated with its disposal.

\footnotetext{
* Correspondence: feedbiotech@gmail.com

'State Key Laboratory of Animal Nutrition, College of Animal Science and

Technology, China Agricultural University, Beijing 100193, China

Full list of author information is available at the end of the article
}

Enzymatic hydrolysis is a particularly attractive technique to convert underutilized RBC into the acceptable and marketable forms. Intriguingly, enzymatic hydrolysis offers several advantages, including mild reaction conditions, high product yields, minimal formation of byproducts, high safety and low energy cost [3]. Proteolysis is measured by degree of hydrolysis (DH), which is a key parameter to determine the nutritional and functional properties of protein hydrolysate $[4,5]$. Thus, it is important for optimizing DH and its involved parameters, such as enzyme concentration, substrate concentration, reaction temperature, hydrolysis time, and $\mathrm{pH}$, to achieve an economical and nutritional protein hydrolysate. Response surface methodology (RSM) is an effective technique applied to optimize food processing operations,

(c) The Author(s). 2018 Open Access This article is distributed under the terms of the Creative Commons Attribution 4.0 International License (http://creativecommons.org/licenses/by/4.0/), which permits unrestricted use, distribution, and 
which can employ several variables simultaneously and describe the overall process $[6,7]$.

In addition to its fundamental nutritional role, the bio-functional features of RBC are now being recognized [8]. It has been shown that protein hydrolysates possess several desirable functional properties, which can be modified by the elevated soluble nitrogenous compounds resulted from the enzymatic hydrolysis [9]. As DH increases the solubility of hydrolysate increases, and it further affects other functional properties like foaming and emulsification [10, 11]. Furthermore, high solubility of protein hydrolysate is a substantially beneficial feature for many food applications. Apart from the functional properties, protein hydrolysates from animal protein sources such as fish [12] and porcine plasma [13], have been shown to possess antioxidant activity to eliminate free radicals and inhibit lipid peroxidation. Moreover, protein hydrolysate with antioxidant activity is a potential antioxidant alternative for its higher concentration without the deleterious effects associated with the use of synthetic equivalents.

To the best of our knowledge, RBCs that are used as sources for preparing hydrolysates are generally obtained from porcine and bovine sources, while the utilization of poultry blood is limited. In this work, we first studied the synergetic effect of neutrase and flavourzyme on the protein derived from duck blood. The processing technology for enzymatic hydrolysis of duck blood cell was subsequently optimized by means of RSM. Importantly, the functional and antioxidant properties of protein hydrolysate as well as its nutritional value were investigated.

\section{Methods}

\section{Chemicals and reagents}

Neutrase (actual activity of 40,000 U/g) and flavourzyme (actual activity of 10,000 U/g) for protein hydrolysis were purchased from Nanning Pangbo Biological Engineering Co. Ltd. (Nanning, China). 2,2-diphenyl-1-picrylhydrazyl (DPPH), ferrozine, linoleic acid, butylated hydroxyltoluene (BHT), ascorbic acid and tocopherol were obtained from Sigma-Aldrich (St. Louis, MO, USA). All other chemicals used were of analytical reagent grade and obtained from commercial sources.

\section{Sample preparation}

Duck blood in this study was sampled from Yangyuan Biological Engineering Co., Beijing, China. Fresh duck blood was immediately centrifuged at $8000 \times g$ and $4{ }^{\circ} \mathrm{C}$ for $10 \mathrm{~min}$ in a High Speed Refrigerated Centrifuge to separate plasma (supernatant) and red blood cell (bottom layer). The red blood cell was kept frozen at $-20^{\circ}$ C until use.

\section{Central composite design}

Based on the manufacturer's information and preliminary experiments of enzymatic hydrolysis, four controllable variables (temperature, substrate concentration, initial $\mathrm{pH}$, and time) were chosen for optimization by RSM using a Central Composite Design (CCD) of experiments (Table 1). Upon the completion of experiments, the mathematical relationship between response (DH) and variables (temperature, substrate concentration, initial $\mathrm{pH}$, and time) was described with a quadratic model as follow:

$$
\begin{aligned}
\mathrm{Y}= & \mathrm{a}_{0}+\mathrm{a}_{1} x_{1}+\mathrm{a}_{2} x_{2}+\mathrm{a}_{3} x_{3}+\mathrm{a}_{4} x_{4}+\mathrm{a}_{12} x_{1} x_{2} \\
& +\mathrm{a}_{13} x_{1} x_{3}+\mathrm{a}_{14} x_{1} x_{4}+\mathrm{a}_{23} x_{2} x_{3}+\mathrm{a}_{24} x_{2} x_{4} \\
& +\mathrm{a}_{34} x_{3} x_{4}+\mathrm{a}_{11} x_{1}^{2}+\mathrm{a}_{22} x_{2}^{2}+\mathrm{a}_{33} x_{3}^{2}+\mathrm{a}_{44} x_{4}^{2}
\end{aligned}
$$

Where $\mathrm{Y}$ is a predicted response, $\mathrm{a}_{0}$ is a constant coefficient (intercept), $a_{1}, a_{2}, a_{3}$ and $a_{4}$ are linear effects, $a_{12}$, $a_{13}, a_{14}, a_{23}, a_{24}$, and $a_{34}$ are interaction effects.

\section{Enzymatic hydrolysis}

The peptide hydrolysate was prepared according to the previous method [14]. Briefly, RBC was adjusted to 7.0 using $1.0 \mathrm{M} \mathrm{NaOH}$ or lactic acid (85\%) and neutrase $(3000 \mathrm{U} / \mathrm{g})$ and flavourzyme $(1000 \mathrm{U} / \mathrm{g})$ alone or together were added to the solution. The mixture was incubated at $50{ }^{\circ} \mathrm{C}$ and $200 \mathrm{rpm}$, and $5 \mathrm{~mL}$ sample was collected every $60 \mathrm{~min}$ to detect the $\mathrm{DH}$. Later, the optimization of enzymatic hydrolysis was carried out according to the experimental design described in Table 1. The peptide hydrolysate was dehydrated by spray drying in a laboratory spray dryer (SD-Basic Spray Dryer, LabPlant, England) with an inlet temperature of $130{ }^{\circ} \mathrm{C}$, outlet temperature of $80^{\circ} \mathrm{C}$.

\section{Determination of the degree of hydrolysis}

The DH was determined with the o-phthaldialdehyde method described by PM Nielsen, D Petersen and C Dambmann [15]. $400 \mu \mathrm{L}$ sample was mixed with $3 \mathrm{~mL}$ OPA reagent, and incubated at room temperature for exactly $2.0 \mathrm{~min}$. Then the absorbance of the mixture was measured at $340 \mathrm{~nm}$ in a UV-visible spectrophotometer (Pgeneral, Beijing, China).

\section{Determination of molecular weight distribution}

The molecular weight distribution profile of the sample was estimated by high-performance gel-filtration chromatography using ÄKTA avant 25 chromatography system and Superdex 75 10/300 GL column (GE Healthcare, Uppsala, Sweden). Samples (10 mg) were dissolved in $1 \mathrm{~mL}$ of $0.01 \mathrm{M}$ Tris- $\mathrm{HCl}$ solution and centrifuged at $12,000 \mathrm{rpm}$ for $10 \mathrm{~min}$. Then supernatant was injected for analysis by HPLC. The results were obtained using UV detector, and the molecular weight was calculated using a 
Table 1 Central composite design matrix, experimental and predicted values for response surface analysis

\begin{tabular}{|c|c|c|c|c|c|c|c|c|c|c|}
\hline \multirow[t]{3}{*}{ Run } & \multicolumn{8}{|c|}{ Independent variables } & \multirow{2}{*}{\multicolumn{2}{|c|}{$\frac{\text { Response }}{\mathrm{DH}(\%)}$}} \\
\hline & \multicolumn{4}{|c|}{ Coded value } & \multicolumn{4}{|c|}{ Actual value } & & \\
\hline & $x_{1}$ & $x_{2}$ & $x_{3}$ & $x_{4}$ & $\mathrm{~T}^{1}\left({ }^{\circ} \mathrm{C}\right)$ & $C^{2}(\%)$ & $\mathrm{pH}$ & Time (h) & Observed & Predicted \\
\hline 1 & -1 & 1 & 1 & -1 & 45 & 18 & 8.0 & 6.0 & 25.45 & 25.42 \\
\hline 2 & -1 & 1 & 1 & 1 & 45 & 18 & 8.0 & 7.0 & 26.46 & 26.99 \\
\hline 3 & 1 & 1 & -1 & -1 & 55 & 18 & 7.0 & 6.0 & 28.77 & 28.58 \\
\hline 4 & 2 & 0 & 0 & 0 & 60 & 16 & 7.5 & 6.5 & 23.64 & 24.14 \\
\hline 5 & 0 & 2 & 0 & 0 & 50 & 20 & 7.5 & 6.5 & 30.66 & 30.77 \\
\hline 6 & 0 & 0 & 0 & 0 & 50 & 16 & 7.5 & 6.5 & 31.26 & 31.91 \\
\hline 7 & 0 & 0 & 0 & 0 & 50 & 16 & 7.5 & 6.5 & 31.46 & 31.91 \\
\hline 8 & 1 & -1 & -1 & -1 & 55 & 14 & 7.0 & 6.0 & 28.14 & 27.73 \\
\hline 9 & 1 & -1 & -1 & 1 & 55 & 14 & 7.0 & 7.0 & 30.55 & 30.83 \\
\hline 10 & 1 & -1 & 1 & 1 & 55 & 14 & 8.0 & 7.0 & 31.68 & 31.54 \\
\hline 11 & 0 & 0 & 0 & 0 & 50 & 16 & 7.5 & 6.5 & 32.16 & 31.91 \\
\hline 12 & -2 & 0 & 0 & 0 & 40 & 16 & 7.5 & 6.5 & 19.13 & 18.27 \\
\hline 13 & -1 & -1 & 1 & -1 & 45 & 14 & 8.0 & 6.0 & 25.82 & 26.15 \\
\hline 14 & 1 & 1 & -1 & 1 & 55 & 18 & 7.0 & 7.0 & 31.17 & 30.96 \\
\hline 15 & 0 & 0 & 0 & 0 & 50 & 16 & 7.5 & 6.5 & 31.81 & 31.91 \\
\hline 16 & 0 & 0 & 0 & 0 & 50 & 16 & 7.5 & 6.5 & 32.56 & 31.91 \\
\hline 17 & 1 & -1 & 1 & -1 & 55 & 14 & 8.0 & 6.0 & 28.30 & 28.56 \\
\hline 18 & -1 & 1 & -1 & -1 & 45 & 18 & 7.0 & 6.0 & 25.54 & 25.80 \\
\hline 19 & -1 & 1 & -1 & 1 & 45 & 18 & 7.0 & 7.0 & 27.50 & 27.49 \\
\hline 20 & 0 & 0 & -2 & 0 & 50 & 16 & 6.5 & 6.5 & 29.79 & 29.83 \\
\hline 21 & 0 & 0 & 0 & 0 & 50 & 16 & 7.5 & 6.5 & 32.38 & 31.91 \\
\hline 22 & 1 & 1 & 1 & -1 & 55 & 18 & 8.0 & 6.0 & 28.97 & 28.86 \\
\hline 23 & 0 & 0 & 0 & 2 & 50 & 16 & 7.5 & 7.5 & 33.61 & 33.27 \\
\hline 24 & -1 & -1 & -1 & 1 & 45 & 14 & 7.0 & 7.0 & 28.15 & 28.38 \\
\hline 25 & 0 & 0 & 2 & 0 & 50 & 16 & 8.5 & 6.5 & 30.57 & 30.16 \\
\hline 26 & 0 & -2 & 0 & 0 & 50 & 12 & 7.5 & 6.5 & 31.84 & 31.36 \\
\hline 27 & 0 & 0 & 0 & -2 & 50 & 16 & 7.5 & 5.5 & 28.63 & 28.60 \\
\hline 28 & 1 & 1 & 1 & 1 & 55 & 18 & 8.0 & 7.0 & 31.21 & 31.12 \\
\hline 29 & -1 & -1 & 1 & 1 & 45 & 14 & 8.0 & 7.0 & 28.00 & 28.44 \\
\hline 30 & -1 & -1 & -1 & -1 & 45 & 14 & 7.0 & 6.0 & 25.64 & 25.98 \\
\hline
\end{tabular}

${ }^{1}$ Temperature

${ }^{2}$ substrate concentration

calibration curve produced by various known concentrations of standard proteins.

\section{Amino acid composition}

Amino acid compositions of protein and hydrolysate were measured by the amino acid auto-analyzer (Hitachi High-Technologies Corporation, Japan). Fifteen of amino acids were determined after $24 \mathrm{~h}$ of acid hydrolysis using $6 \mathrm{M} \mathrm{HCl}$ at $110{ }^{\circ} \mathrm{C}$. Methionine and cystine were determined from $24 \mathrm{~h}$ acid hydrolysates following formic acid oxidation of the samples. The amount of each amino acid in the samples was calculated and expressed as a percentage of the total sample weight.

\section{Determination of functional properties Solubility}

Solubility was determined in triplicate according to the method of I Suppavorasatit, EG De Mejia and KR Cadwallader [16] with some modifications. $200 \mathrm{mg}$ of samples were dispersed in $20 \mathrm{mM}$ citrate-phosphate buffers of various $\mathrm{pH}$ values. All samples were stirred at $25{ }^{\circ} \mathrm{C}$ overnight and then centrifuged at $5000 \times g$ for $15 \mathrm{~min}$. Protein in the supernatant and total protein in sample 
were determined by the BCA Quantitation Kit (Beijing BLKW Biotechnology Co., Ltd.). The solubility was calculated as follows:

$$
\text { Solubility }(\%)=[(\text { protein in supernatant }) /(\text { total protein })]
$$

$$
\times 100
$$

\section{Emulsifying properties}

Emulsifying activity index (EAI) and emulsion stability index (ESI) of protein samples were determined following the method of Q Liu, B Kong, YL Xiong and X Xia [13]. Emulsions of protein dispersions were prepared by mixing $10 \mathrm{~mL}$ of vegetable oil with $30 \mathrm{~mL}$ of $0.2 \%(w / v)$ protein dispersion in $20 \mathrm{mM}$ citrate-phosphate buffer solution at different $\mathrm{pH}$ values. Then the mixtures were homogenized at $20,000 \mathrm{rpm}$ for $1 \mathrm{~min}$ using a homogenizer (IKA T18, Staufen, Germany). An aliquot of the emulsion $(50 \mu \mathrm{L})$ was immediately mixed with $5 \mathrm{~mL}$ of $0.1 \%(\mathrm{w} / \mathrm{v})$ sodium dodecyl sulphate (SDS) solution for $15 \mathrm{~min}$. The absorbance of mixture was measured at $500 \mathrm{~nm}$ with a UV-visible spectrophotometer. EAI and ESI were calculated as follows:

$$
\text { EAI }\left(\mathrm{m}^{2} / \mathrm{g}\right)=\left(2 \times 2.303 \times \mathrm{A}_{0}\right) /[0.25 \times \text { protein weight }(\mathrm{g})]
$$

$$
\mathrm{ESI}(\min )=\left[\mathrm{A}_{0} /\left(\mathrm{A}_{0}-\mathrm{A}_{15}\right)\right] \times 15
$$

where $\mathrm{A}_{0}$ and $\mathrm{A}_{15}$ are the absorbance at time 0 and $15 \mathrm{~min}$.

\section{Foaming properties}

Foaming capacity and foaming stability of samples were evaluated according to the method described by A Kato, $\mathrm{T}$ Fugishing, N Matsudomi and K Kobashi [17] with some modifications. Protein dispersions $(0.5 \%, w / v)$ prepared in $20 \mathrm{mM}$ citrate-phosphate buffer at different $\mathrm{pH}$ values, were homogenized at $18000 \mathrm{rpm}$ for $1 \mathrm{~min}$ using a homogenizer (IKA T18, Staufen, Germany). Foaming capacity was calculated as the percentage of increasing volume upon mixing. Foaming stability was expressed as the percentage of remaining foam after $60 \mathrm{~min}$ without disturbing.

\section{Evaluation of antioxidant activity $D P P H$ radical scavenging activity}

DPPH radical-scavenging activity was determined according to the method of Sun et al. [18] with slight modification. $1.5 \mathrm{~mL}$ of sample solution was mixed with $1.5 \mathrm{~mL}$ of DPPH solution (1.0 mM in $95 \%$ ethanol) at room temperature for $30 \mathrm{~min}$ in the dark. The absorbance of reaction solution was measured at $517 \mathrm{~nm}$.
DPPH radical-scavenging activity was calculated according to the following equation:

$$
\text { Scavenging activity }(\%)=\left(1-\left(\mathrm{A}_{\text {sample }}-\mathrm{A}_{\text {blank }}\right) / \mathrm{A}_{\text {control }}\right) \times 100
$$

where $A_{\text {sample }}$ was sample absorbance; $A_{\text {blank }}$ was the blank absorbance without DPPH solution; $\mathrm{A}_{\text {control }}$ was the absorbance of control group without sample.

\section{Reducing power}

The reducing power was determined according to the method of A Taheri, KH Sabeena Farvin, C Jacobsen and CP Baron [19]. $1 \mathrm{~mL}$ sample was mixed with $1 \mathrm{~mL}$ of $0.2 \mathrm{M}$ phosphate buffer $(\mathrm{pH} 6.6)$ and $1 \mathrm{~mL}$ of $1 \%(w / v)$ potassium ferricyanide. The mixture was incubated at $50{ }^{\circ} \mathrm{C}$ for $20 \mathrm{~min}$ and $1 \mathrm{~mL} \mathrm{10 \% (w/v)} \mathrm{trichloroacetic}$ acid was added to this mixture. An aliquot of $2 \mathrm{~mL}$ from this incubation mixture was mixed with $2 \mathrm{~mL}$ of distill water and $0.4 \mathrm{~mL}$ of $0.1 \%(\mathrm{w} / \mathrm{v})$ ferric chloride. After reaction for $10 \mathrm{~min}$, the absorbance of reaction solution was measured at $700 \mathrm{~nm}$. The reducing power is represented as the absorbance, and a higher absorbance indicates a stronger reducing power.

\section{Metal chelating activity}

The chelating activity on $\mathrm{Fe}^{2+}$ was determined according to the reported method A Taheri, KH Sabeena Farvin, C Jacobsen and CP Baron [19]. $1.0 \mathrm{~mL}$ of $20 \mu \mathrm{M} \mathrm{FeCl}_{2}$ was mixed with $1.0 \mathrm{~mL}$ of $0.5 \mathrm{mM}$ ferrozine. The mixture was then reacted with $0.5 \mathrm{~mL}$ of sample for $20 \mathrm{~min}$ at room temperature. The absorbance was read at $562 \mathrm{~nm}$. The ability to chelate the ferrous ion was calculated as follows:

Chelating ability $(\%)=\left(1\right.$-absorbance sample $_{\text {absorbance }}$ blank $) \times 100$

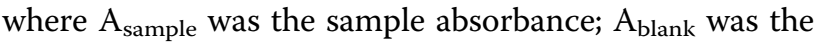
blank absorbance.

\section{Lipid peroxidation assay}

The lipid peroxidation inhibition ability of sample was detected in a linoleic acid model system [20]. Briefly, the sample $(5.0 \mathrm{mg}$ ) was dissolved in $10 \mathrm{~mL}$ of $50 \mathrm{mM}$ phosphate buffer ( $\mathrm{pH} 7.0$ ) and added to a solution of $130 \mu \mathrm{L}$ of linoleic acid in $10 \mathrm{~mL}$ of $99.5 \%$ ethanol. Then the total volume was adjusted to $25 \mathrm{~mL}$ with distill water. The mixture was incubated at $40{ }^{\circ} \mathrm{C}$ in a dark room, and the degree of oxidation was evaluated for 8 days by measuring ferric thiocyanate values. The reaction solution $(100 \mu \mathrm{L})$ incubated in the linoleic acid model system was mixed with $4.7 \mathrm{~mL}$ of $75 \%$ ethanol, $0.1 \mathrm{~mL}$ of $30 \%(w / v)$ ammonium thiocyanate, and $0.1 \mathrm{~mL}$ of $20 \mathrm{mM}$ ferrous chloride solution in $3.5 \% \mathrm{HCl}$. After $3 \mathrm{~min}$, the degree of color development that represents linoleic acid oxidation 
was measured at $500 \mathrm{~nm}$. The absorbance value indicates the degree of lipid peroxidation.

\section{Statistical analysis}

ANOVA was used to determine the differences among treatments $(P<0.05)$ by the statistical program JMP 12.0 software package (SAS Institute Inc.) and Minitab 16 statistical software (State College, PA). The resulting data were investigated graphically using Origin 9.0 software (OriginLab, Northampton, MA).

\section{Results and discussion}

\section{Synergistic effect of neutrase and flavourzyme}

To obtain a hydrolysate with high nutritional value, the protein hydrolysates should enrich low molecular weight peptides, directly correlating with the degree of proteolysis. Thus, neutrase and flavourzyme were incubated together or individually with $\mathrm{RBC}$ to evaluate the degree of enzymatic hydrolysis. Not surprising, DH increased over time until reach a plateau in the treatment of neutrase, flavourzyme or their combination (Fig. 1). Compared to the group with only neutrase or flavourzyme, DH was significantly higher when both two proteases were added. After $10 \mathrm{~h}$ incubation with both neutrase and flavourzyme, DH of hydrolysate reached $31.41 \pm$ $0.56 \%$. Comparably, DH reached $10.69 \pm 0.21 \%$ and $12.02 \pm 1.22 \%$, respectively, for only neutrase or flavourzyme group. It was obvious that the mixture of neutrase and flavourzyme could cause higher hydrolysis of RBC as compared to the single protease treatment. Based on

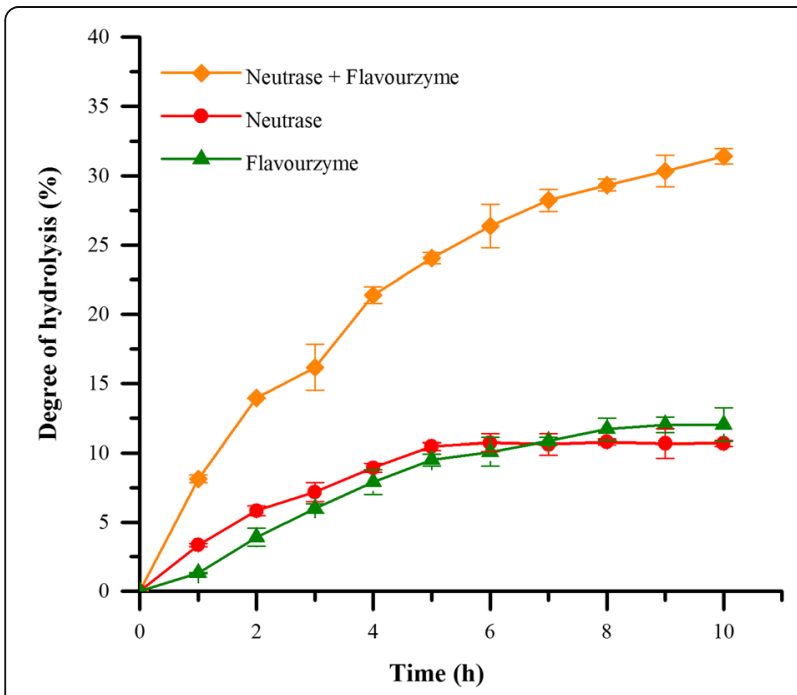

Fig. 1 Time-course hydrolysis of protein from duck blood red cell. Separate hydrolysis: $3000 \mathrm{U} / \mathrm{g}$ neutrase (circle) or $1000 \mathrm{U} / \mathrm{g}$ flavourzyme (triangle); simultaneous hydrolysis: $3000 \mathrm{U} / \mathrm{g}$ neutrase and $1000 \mathrm{U} / \mathrm{g}$ flavourzyme (diamond) the results obtained above, we reasoned that endoproteinase (neutrase) combining with exopeptidase (flavourzyme) could accelerate the enzymatic hydrolysis and obtain great degree of degradation.

\section{Optimization of process parameters}

Experimental data from CCD were obtained using 30 combinations of four factors: temperature, substrate concentration, initial $\mathrm{pH}$, and time (Table 1). In terms of actual factors, an empirical relationship between $\mathrm{DH}$ and variables without considering non-significant terms could be expressed by the second-order polynomial equation below:

$$
\begin{aligned}
\mathrm{DH}(\%)=-395.02+ & 2.53 x_{1}+9.64 x_{2}+27.74 x_{3}+14.34 x_{4} \\
& +0.03 x_{1} x_{2}-0.14 x_{1} x_{3}-0.18 x_{1} x_{4} \\
& +0.07 x_{2} x_{3}+0.07 x_{2} x_{4}-0.05 x_{1}^{2}-0.11 x_{2}^{2} \\
& -1.91 x_{3}^{2}-0.97 x_{4}^{2}
\end{aligned}
$$

According to the results of ANOVA for examining the model shown in Additional file 1: Table S1, F-value of 469.47 implied that the model was significant with a highly satisfactory value of $R^{2}$ of $96.31 \%$, which indicated that only $3.69 \%$ of the total variation was not explained by the model. The model also resulted in high value of the adjusted determination coefficient (adjusted $R^{2}=0.9610$ ) with no significant lack of fit $(p=0.467>0.05)$, indicating the regression modeling procedure was acceptable.

The second-order response surface plots were drawn to illustrate the main and interactive effects of the independent variables on the DH (Fig. 2). Temperature played a maximal linear influence on the $\mathrm{DH}$, and this factor also had significant interactions with other three variables. DH increased as a function of temperature until around $49-51{ }^{\circ} \mathrm{C}$, after which it dropped with further increases in temperature (Fig. 2a). Though not readily apparent, Fig. 2a showed that at lower temperature DH decreased with increasing substrate concentration; however, the lower-left corner of the response surface showed that at higher temperature DH increased with the rise of concentration. In contrast, the response surface in Fig. $2 \mathrm{~b}$ showed that DH increased slowly with the rise of substrate concentration at shorter time, and $\mathrm{DH}$ declined with increasing substrate concentration over time, which was similar to the report of D Peričin, L Radulović-Popović, Ž Vaštag, S Mađarev-Popović and S Trivić [21] about the effects of time and enzyme concentration. This phenomenon occurred might be related to the inherent characters of the enzyme system whatever the substrate was. As the most important linear variables of influencing the $\mathrm{DH}$ values, temperature and 

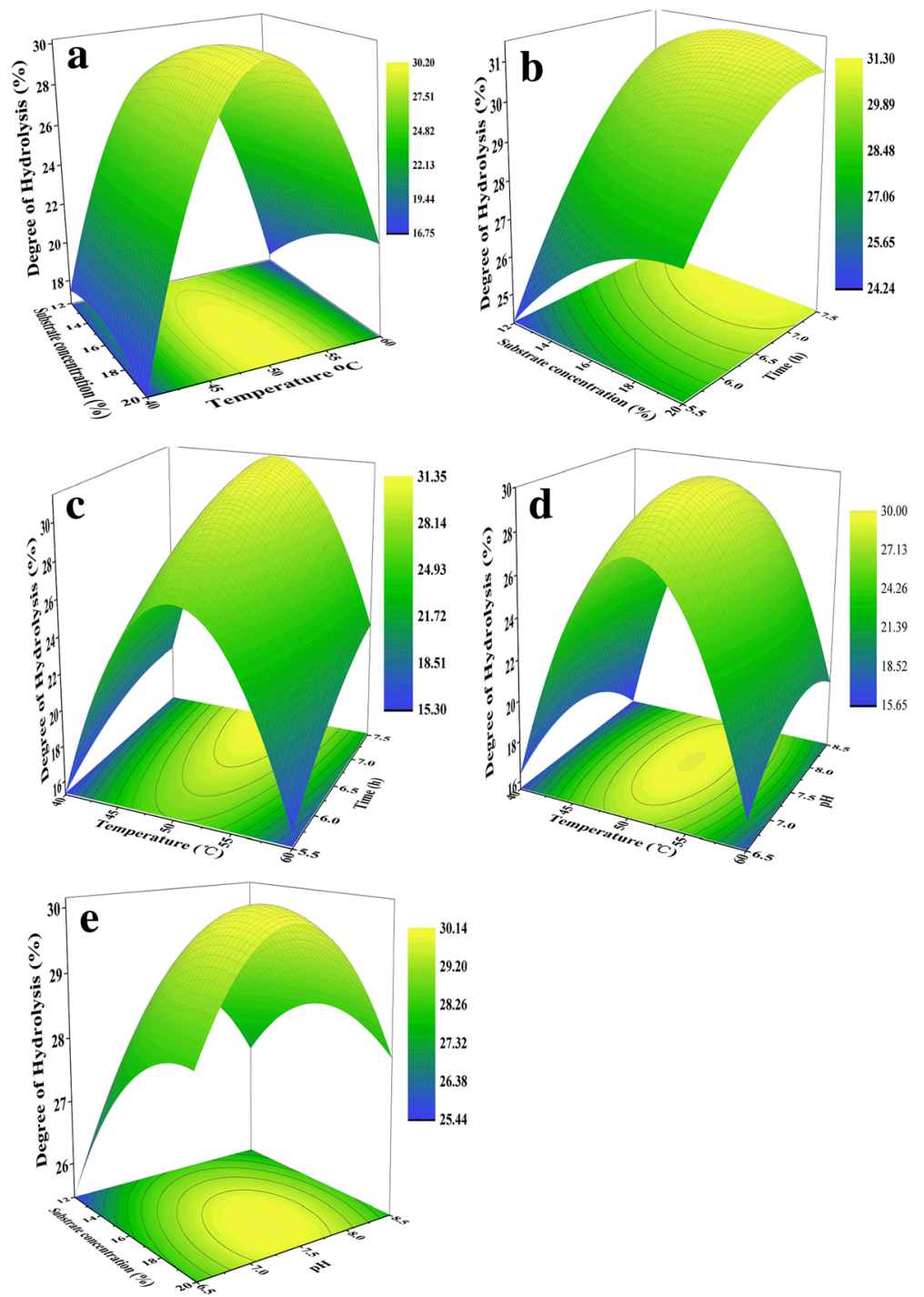

Fig. 2 Response surface plots for degree of hydrolysis $(\mathrm{DH})$ as a function of $\mathbf{a}$ temperature and substrate concentration, $\mathbf{b}$ substrate concentration and time, $\mathbf{c}$ temperature and time, $\mathbf{d}$ temperature and initial $\mathrm{pH}$, e substrate concentration and initial $\mathrm{pH}$

time had a clear interaction effect on $\mathrm{DH}$ as shown in Fig. 2c. Unlike the correlation between $\mathrm{DH}$ and temperature, the $\mathrm{DH}$ values increased with increasing time, which was similar to the reports by other researchers [21-23]. Fig. 2d showed that initial $\mathrm{pH}$ played a minor role in the improvement of $\mathrm{DH}$, but the interaction between $\mathrm{pH}$ and temperature was significant. Greater $\mathrm{DH}$ was obtained at high $\mathrm{pH}$ values, with the highest $\mathrm{DH}$ occurring at around $\mathrm{pH}$ 7.3-7.6, after which DH declined. This phenomenon could be explained by a loss of enzyme stability with the increment of $\mathrm{pH}$ [16]. As shown in Fig. 2e, the lowest DH was observed both at the combination of low substrate concentration and low $\mathrm{pH}$ or at high substrate concentration and high $\mathrm{pH}$.

The numerical optimization of hydrolysis parameters was carried out using JMP Pro 12 software based on the initial experimental results. To obtain the highest $\mathrm{DH}$, the experiment was conducted according to the predicted and optimal conditions of $51{ }^{\circ} \mathrm{C}$ temperature, $14 \%$ substrate concentration $(w / v), 7.0 \mathrm{pH}$, and $7.5 \mathrm{~h}$ time. The result from confirmation experiment at optimum point was $32.06 \pm 0.59 \%$ for $\mathrm{DH}$ that was predicted by the model as $32.80 \%$. The experimental value agreed with the value predicted by the model within a $95 \%$ confidence interval, showing the validity of this response model. 


\section{Molecular weight distribution}

The protein and its hydrolysate produced under optimal conditions were analyzed using high-performance gel-filtration chromatography (Fig. 3). As anticipated, the protein of $\mathrm{RBC}$ was rich in peptide fractions with a molecular weight higher than $10 \mathrm{kDa}$ (Fig. 3a), corresponding to the hemoglobin and globin. Whereas red blood cell hydrolysate $(\mathrm{RBCH})$ was mainly composed of lower molecular weight peptides, with a noticeable amount of $94.79 \%$ lower than $10 \mathrm{kDa}$ (Fig. 3b). Approximately $26.65 \%$ of the peptides in the hydrolysate had a molecular mass between $10 \mathrm{kDa}$ and $3 \mathrm{kDa}$, and the fraction with a molecular mass lower than $3 \mathrm{kDa}$ was $68.14 \%$. The difference of molecular weight distributions between $\mathrm{RBC}$ and $\mathrm{RBCH}$ suggested that the enzymatic hydrolysis rendered mostly peptides smaller than $3 \mathrm{kDa}$. The obvious downward shift from macromolecular proteins to low molecular weight peptides, implied that the blood protein after hydrolysis could be of high nutritive value [24].

On the other hand, the uniqueness in distribution of peptide fractions might contribute to special functionalities and characterizations of the protein. It is well established that these peptides $(<6 \mathrm{kDa})$ may have the bioactive activities, such as antioxidative, antimicrobial, and antihypertensive functions $[25,26]$. As shown in Fig. $3, \mathrm{BCH}$ was abundant in peptide fractions and amino acid residues, implying its potential biological properties.

\section{Amino acid profile}

The amino acid composition and chemical scores of $\mathrm{RBCH}$ are shown in Table 2. Overall, the amino acid profiles of $\mathrm{RBC}$ and $\mathrm{RBCH}$ were similar, while the former was slight lower than that of latter. The essential amino acids of $\mathrm{RBCH}$ accounted for more than $50 \%$ of the total amino acids, which was well above $36 \%$, considering adequate for an ideal protein [27]. A generally accepted method to evaluate the nutritional quality of a protein is chemical score, which compares
Table 2 Total amino acid compositions of red blood cell (RBC) and its hydrolysate $(\mathrm{RBCH})$

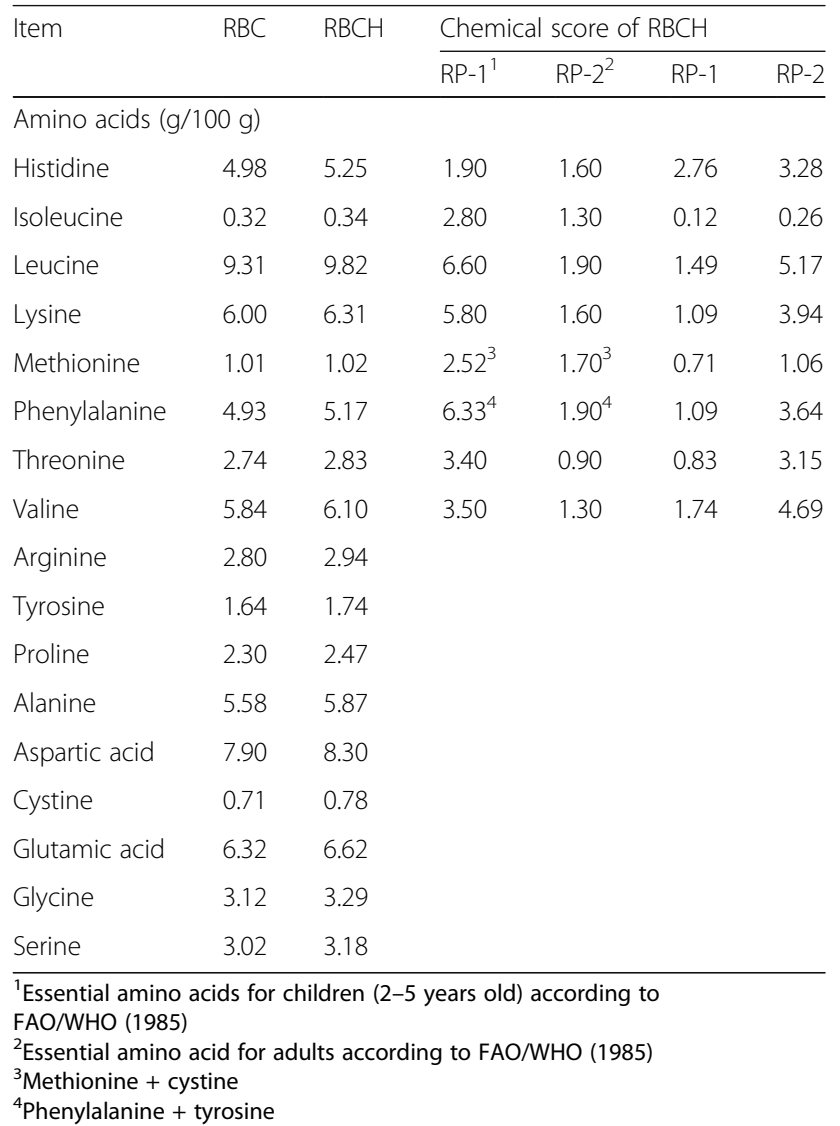

the levels of essential amino acids between test and standard proteins $[28,29]$. We thus computed the chemical scores of RBCH based on the essential amino acids reference standards of FAO/WHO [30] for children (2-5 years old) and adults. In the case of children, the chemical scores of $\mathrm{RBCH}$ showed that isoleucine was the most limiting amino acids, and others (except methionine and threonine) were mainly present in sufficient or excess quantity for meeting their requirements. As for the adults,
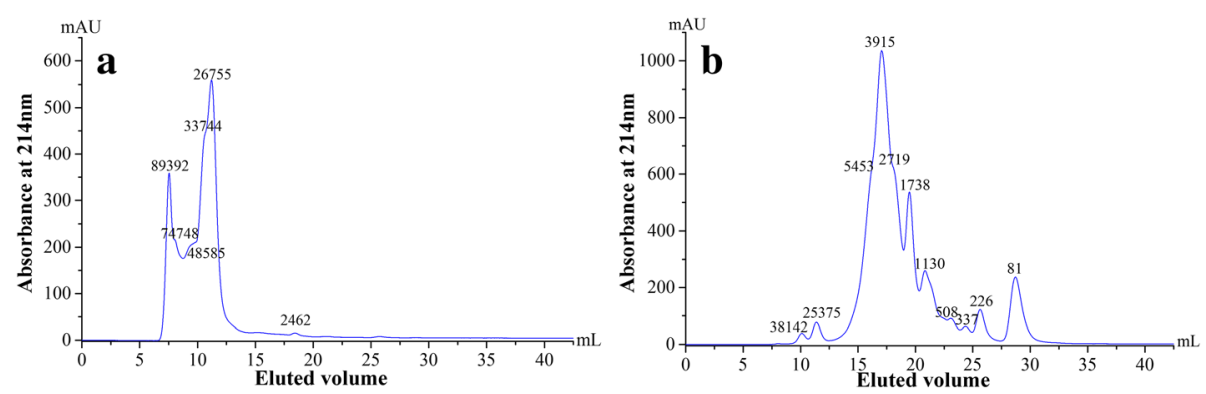

Fig. 3 Molecular weight distribution of red blood cell protein (a) and its hydrolysate (b) 
the essential amino acids except isoleucine could cover daily requirements. As the N Bhaskar and N Mahendrakar [28] demonstrated, the nutritive value of any high-quality protein depended on the capacity to fulfill the requirements of organisms. Therefore, in spite of minor deficiencies in certain essential amino acids, $\mathrm{RBCH}$ has the potential to be a nutritional ingredient used in the food and feed industry.

\section{Functional properties of hydrolysate Solubility}

Fig. 4 shows protein solubility profiles of RBC and $\mathrm{RBCH}$ in the $\mathrm{pH}$ ranges of $1.0-10.0$. Both showed similar solubility profiles that exhibited a $\mathrm{V}$-shaped curve, revealing remarkable $\mathrm{pH}$-dependent solubility. $\mathrm{RBC}$ and $\mathrm{RBCH}$ had the lowest solubility at $\mathrm{pH} 6.0$ which might be ascribed to the isoelectric region, while the solubility increased on either side of this $\mathrm{pH}$ value. Compared with the native protein, the hydrolysate was soluble highly over a wide $\mathrm{pH}$ range with more than $80 \%$ solubility, corresponding to the findings of SY Naqash and R Nazeer [31], B Giménez, A Alemán, P Montero and M Gómez-Guillén [32] and M Chalamaiah, T Jyothirmayi, PV Diwan and BD Kumar [33]. This elevated solubility after hydrolysis was due to the degradation of proteins to low molecular weight peptides, which were expected to have proportionally more polar residues than the parent proteins, with the capacity of forming hydrogen bonds with water and thus increasing solubility $[10,11,34]$.

\section{Emulsifying properties}

Emulsifying activity index (EAI) and emulsion stability index (ESI) of $\mathrm{RBC}$ and its hydrolysate at various $\mathrm{pH}$ are shown in Table 3 . Approximately $33 \mathrm{~m}^{2} / \mathrm{g}$ of EAI at different $\mathrm{pH}$ ranges was observed in the case of $\mathrm{RBC}$, which

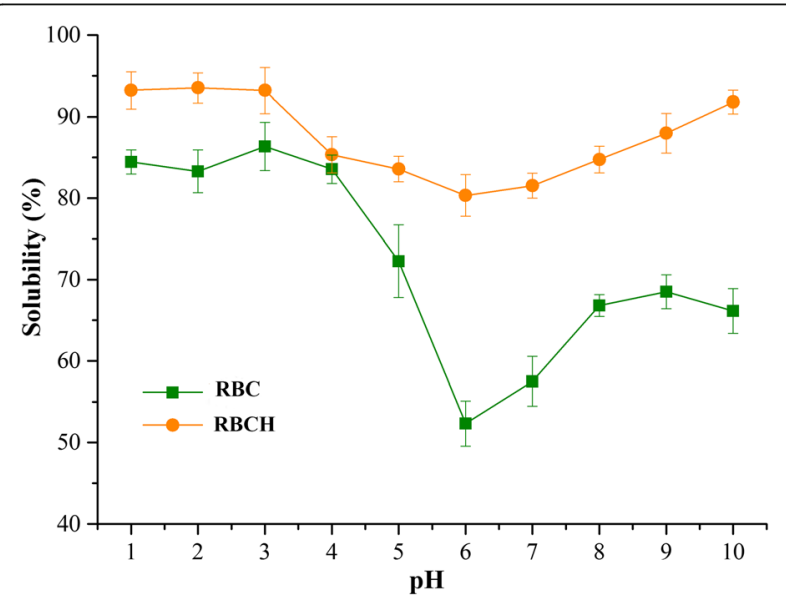

Fig. 4 Solubility of red blood cell hydrolysate measured at different $\mathrm{pH}$ values
Table 3 Emulsifying activity index (EAl, $\mathrm{m}^{2} / \mathrm{g}$ ) and emulsion stability index (ESI, min) of red blood cell (RBC) and its hydrolysate $(\mathrm{RBCH})$ with different $\mathrm{pH}$ values ${ }^{1}$

\begin{tabular}{llllll}
\hline $\mathrm{pH}$ & $\mathrm{EAI}\left(\mathrm{m}^{2} / \mathrm{g}\right)$ & & $\mathrm{ESI}(\mathrm{min})$ \\
\cline { 2 - 3 } \cline { 5 - 6 } & $\mathrm{RBC}$ & $\mathrm{RBCH}$ & $\mathrm{RBC}$ & $\mathrm{RBCH}$ \\
\hline 2 & $34.37 \pm 2.56 \mathrm{abB}$ & $51.24 \pm 0.89 \mathrm{bA}$ & $30.19 \pm 2.44 \mathrm{aB}$ & $80.47 \pm 2.65 \mathrm{aA}$ \\
4 & $33.1 \pm 1.18 \mathrm{abA}$ & $24.12 \pm 1.03 \mathrm{cB}$ & $21.11 \pm 0.69 \mathrm{bcB}$ & $65.19 \pm 2.81 \mathrm{bA}$ \\
6 & $32.18 \pm 1.29 \mathrm{bA}$ & $13.93 \pm 0.53 \mathrm{~dB}$ & & $16.71 \pm 0.58 \mathrm{~dB}$ & $23.21 \pm 1.78 \mathrm{dA}$ \\
8 & $35.45 \pm 1.52 \mathrm{aB}$ & $51.89 \pm 0.63 \mathrm{bA}$ & & $22.33 \pm 1.23 \mathrm{bB}$ & $52.99 \pm 0.33 \mathrm{cA}$ \\
10 & $33.66 \pm 0.92 \mathrm{abB}$ & $71.99 \pm 1.18 \mathrm{aA}$ & & $19.34 \pm 0.60 \mathrm{cB}$ & $23.34 \pm 1.52 \mathrm{dA}$ \\
\hline
\end{tabular}

${ }^{1}$ Average \pm standard deviation $(n=3)$. Within columns, values with same lowercase letters are not significantly different at $p>0.05$. Within rows, values with same uppercase letters are not significantly different at $p>0.05$

displayed no significant difference $(p>0.05)$ with increasing $\mathrm{pH}$ values. However, it was significantly lower than that of $\mathrm{RBCH}(p<0.05)$ at all $\mathrm{pH}$ values except at $\mathrm{pH} 4$ and $\mathrm{pH} 6$ where the $\mathrm{RBC}$ exhibited higher emulsifying capacity. With regard to the hydrolysate, maximum EAI was $71.99 \pm 1.18 \mathrm{~m}^{2} / \mathrm{g}$ at $\mathrm{pH} 10$ and minimum was at $\mathrm{pH} 6\left(13.93 \pm 0.53 \mathrm{~m}^{2} / \mathrm{g}\right)$. Interestingly, despite $\mathrm{RBCH}$ having more smaller peptides than RBC (Fig. 3), it still had higher EAI values as the $\mathrm{pH}$ was further away the isoelectric regions. The behavior seems to contradict against view that the size and molecular weight of peptides play positive effect on the emulsifying properties [35, 36]. As HG Kristinsson and BA Rasco [37] reported, whereas in fact there was no explicit relationship between the peptide length and emulsification, the physicochemical characters of peptides might play an important role in their functional properties.

Likewise, the lowest ESI of both RBC and RBCH were found at $\mathrm{pH}$ 6.0, with coincidental decrease in solubility. This phenomenon was mainly attributed to the net charge of the protein molecules or the decreased solubility around the isoelectric point [38]. $\mathrm{RBCH}$ exhibited much stronger emulsion stability than $\mathrm{RBC}$ at all observed $\mathrm{pH}$ values, which might be explained by the unique properties of hydrolysate and the mixed enzyme systems.

\section{Foaming properties}

Foaming capacity and foaming stability of protein and peptide hydrolysate were measured in different $\mathrm{pH}$ values (Table 4). Foaming capacity of RBC was significantly lower than that of $\mathrm{RBCH}(p<0.05)$, possibly due to the higher solubility and flexibility of hydrolysate to form good foam by increasing the interaction at the air-water interface and reducing surface tension. Both had the lowest foaming capacity values at $\mathrm{pH}$ 6.0, corresponding to the emulsifying properties. The highest values observed at $\mathrm{pH} 2.0$ were $12.67 \pm 0.94 \%$ and 39.38 $\pm 0.88 \%$ for $\mathrm{RBC}$ and $\mathrm{RBCH}$, respectively. Although we are not aware of comparable results for $\mathrm{RBCH}$, the 
Table 4 Foaming capacity (\%) and foaming stability (\%) of red blood cell (RBC) and its hydrolysate $(\mathrm{RBCH})$ with different $\mathrm{pH}$ values $^{a}$

\begin{tabular}{llllll}
\hline $\mathrm{pH}$ & \multicolumn{2}{l}{ Foaming capacity (\%) } & & \multicolumn{2}{l}{ Foaming stability (\%) } \\
\cline { 2 - 3 } \cline { 5 - 6 } & RBC & RBCH & & RBC & RBCH \\
\hline 2 & $12.67 \pm 0.94 \mathrm{aB}$ & $39.38 \pm 0.88 \mathrm{aA}$ & & $9.83 \pm 0.89 \mathrm{aB}$ & $30.00 \pm 1.41 \mathrm{aA}$ \\
4 & $11.50 \pm 0.24 \mathrm{bB}$ & $28.75 \pm 0.35 \mathrm{bA}$ & & $9.66 \pm 0.05 \mathrm{aB}$ & $16.00 \pm 1.71 \mathrm{cA}$ \\
6 & $3.33 \pm 0.01 \mathrm{eB}$ & $10.25 \pm 0.35 \mathrm{dA}$ & & $0.67 \pm 0.09 \mathrm{cB}$ & $8.50 \pm 0.38 \mathrm{dA}$ \\
8 & $6.67 \pm 0.14 \mathrm{~dB}$ & $26.50 \pm 0.71 \mathrm{CA}$ & & $5.67 \pm 0.94 \mathrm{bB}$ & $18.75 \pm 1.06 \mathrm{bA}$ \\
10 & $10.00 \pm 0.94 \mathrm{cB}$ & $28.75 \pm 0.35 \mathrm{bA}$ & & $6.33 \pm 0.01 \mathrm{bB}$ & $19.50 \pm 1.41 \mathrm{bA}$ \\
\hline
\end{tabular}

${ }^{a}$ Average \pm standard deviation $(n=3)$. Within columns, values with same lowercase letters are not significantly different at $p>0.05$. Within rows, values with same uppercase letters are not significantly different at $p>0.05$

similar behaviors on foaming properties of hydrolysates from other by-products have been observed by researchers [31, 35]. Conversely, V Klompong, S Benjakul, D Kantachote and F Shahidi [10] found that foaming capacity of hydrolysate decreased at very acidic or alkaline $\mathrm{pH}$ due to the ionic repulsion of peptides. Those paradoxical results seem to be involved in the composition and net charge of peptides.

Foam expansions after whipping were monitored for $60 \mathrm{~min}$ to evaluate the foaming stability. Both RBC and its hydrolysate presented the comparable trends on the foaming stability with an increase of $\mathrm{pH}$ values. Further, there are notable differences in the values of foaming stability between $\mathrm{RBC}$ and $\mathrm{RBCH}$. The latter exhibited a relatively high foaming stability, giving the credit to the thick cohesive layer around the air bubble formed by peptides. The lowest values were found at $\mathrm{pH} 6.0$ for these two samples, which coincided with the precipitation of the large protein molecules at their isoelectric $\mathrm{pH}$. Hence, solubility made a considerable contribution to the foaming behaviors as well as emulsifying properties.

\section{Antioxidant activity of hydrolysate DPPH radical scavenging activity}

DPPH radical scavenging activities of hydrolysates at different concentrations $(0-10.0 \mathrm{mg} / \mathrm{mL})$ were measured and depicted in Fig. 5a. Clearly, the DPPH radical scavenging activity showed a concentration dependency, increased with increasing concentration and thereafter reached a plateau. This indicated that $\mathrm{RBCH}$ possessed hydrogen donating capability to suppress the radical chain reaction and convert DPPH radicals to harmless substances. The $\mathrm{IC}_{50}$ value of $\mathrm{RBCH}$ was $4.16 \mathrm{mg} / \mathrm{mL}$,
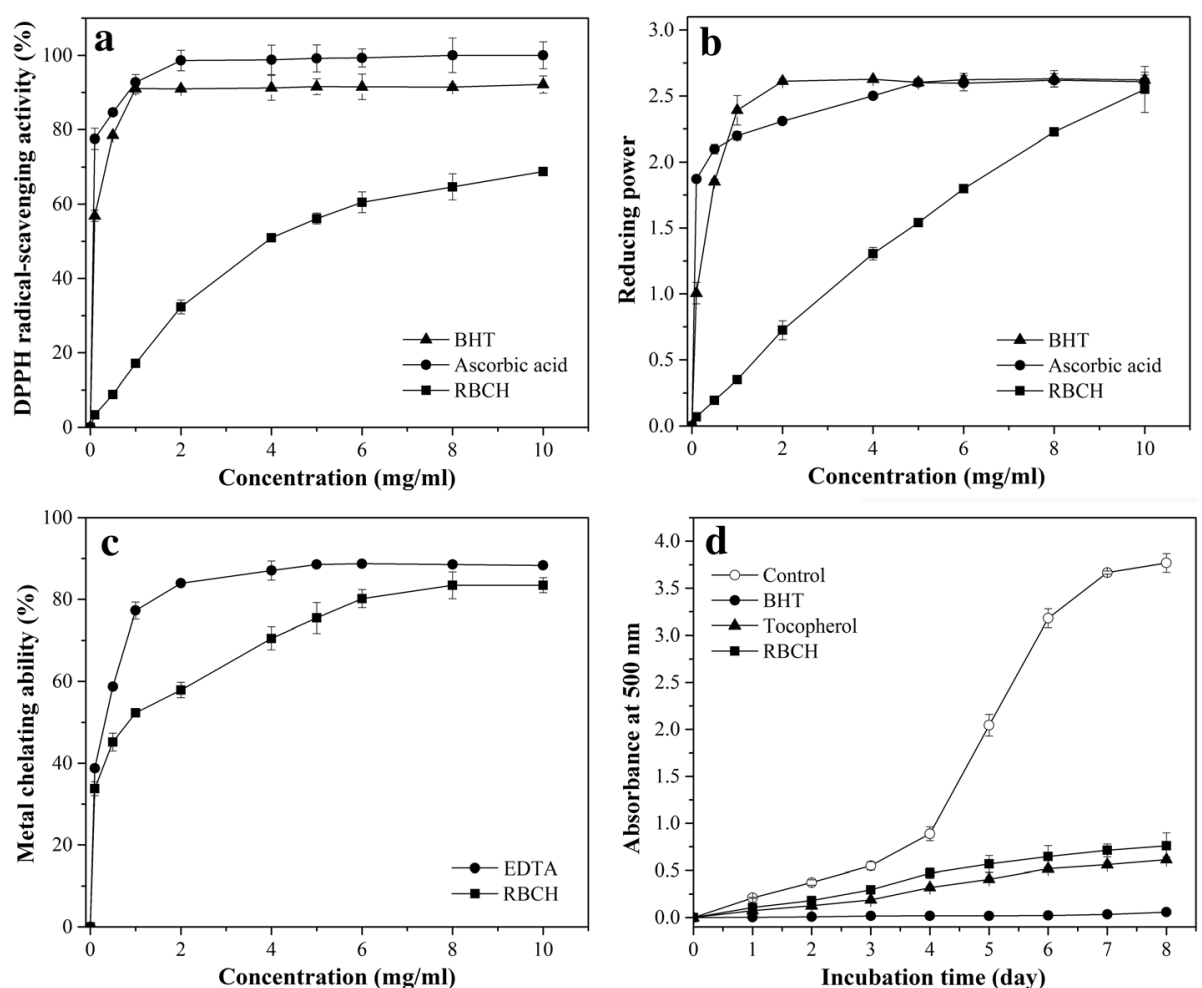

Fig. 5 DPPH radical scavenging activity (a), reducing ability (b), metal chelating activity (c) and lipid peroxidation inhibition activity (d) of red blood cell hydrolysate $(\mathrm{RBCH})$ at different concentrations 
which was similar to those peptides like PYFNK $(4.11 \mathrm{mg} /$ $\mathrm{mL}$ ) [39] and GVPLT (4.54 mg/mL) [40] derived from protein hydrolysates. Many researchers reported that low molecular weight peptides and some amino acids, with higher chance to cross the intestinal barrier and exert biological effects, possessed strong radical-scavenging activity [40-42]. Consequently, we presume that the small peptides and amino acids in hydrolysate may at least partially contribute to the DPPH radical scavenging activity.

\section{Reducing power}

Similarly, RBCH exhibited significant reducing ability with a dose-response relationship. As Fig. 5b showed, there was a linear and positive correlation between reducing power and concentration of $\mathrm{RBCH}$. When the hydrolysate concentration increased from 0.1 to $10 \mathrm{mg} /$ $\mathrm{mL}$, the absorbance at $700 \mathrm{~nm}$ represented the reducing ability was an almost linear increase from 0.07 to 2.55 . The reducing power obtained in this work was higher than that of muscle protein hydrolysate [31], rapeseed peptides [43] and cod protein hydrolysate [44] under the same concentration, but it was similar to the absorbance of 0.69 at $2 \mathrm{mg} / \mathrm{mL}$ for a hydrolysate derived from alfalfa leaf proteins [45]. Although $\mathrm{RBCH}$ displayed outstanding reducing ability, it was still inefficient compared to BHT and ascorbic acid. Within the concentration ranges of $0.50-10.0 \mathrm{mg} / \mathrm{mL}$, the reducing power of $\mathrm{RBCH}$ was lower than those of BHT and ascorbic acid, and then got close to them at the highest tested concentration. Overall, the reducing power results revealed that $\mathrm{RBCH}$ possessed excellent reducing capacity to render hydrogen and electron which was involved in the antioxidant activity.

\section{Metal chelating activity}

Transition metals such as $\mathrm{Fe}^{2+}$ and $\mathrm{Cu}^{2+}$, as we all know, are inducers of lipid peroxidation and their chelation facilitates the antioxidation and subsequently prevents food rancidity [46]. We thus evaluated the metal chelating activity of $\mathrm{RBCH}$ against ferrous ion with EDTA as a positive control.

The ferrous ion-chelating effects of $\mathrm{RBCH}$ and EDTA are shown in Fig. 5c. $\mathrm{RBCH}$ had a strong chelating activity to capture ferrous ion to interfere with the formation of ferrous and ferrozine complex. The chelating activity of $\mathrm{RBCH}$ elevated rapidly at the beginning of concentrations $(0-4 \mathrm{mg} / \mathrm{mL})$, and afterwards increased slightly until a plateau was reached. It displayed approximately $75 \%$ chelating effect on $\mathrm{Fe}^{2+}$ ion at a concentration of $5 \mathrm{mg} / \mathrm{mL}$, which was higher than that of hydrolysate derived from pacific hake muscle [47]. The reason may be explained by the possibility that the specific peptide structure and amino acid side chain groups play important roles in terminating the free radical chain reactions and chelating transition metal ions. Peptides derived from many protein sources with abundant hydrophobic amino acids were related with metal-chelating ability [48, 49]. The hydrophobic amino acids of $\mathrm{RBCH}$ accounted for more than $40 \%$ of the total amino acids, which might exert strong ferrous ion chelating ability. In addition, $\mathrm{RBCH}$ rich in histidine and histidine-containing peptides was presumed to have a significant effects on the chelating activity, in accordance with the report of L You, M Zhao, JM Regenstein and J Ren [50]. Our data implied that RBCH had an effective capacity for iron binding, suggesting that its action as an antioxidant might be associated with its iron binding ability.

\section{Lipid peroxidation}

Lipid peroxidation can cause deleterious effects in foods via forming secondary breakdown products of lipid peroxides and further generate rancid and toxic products. Therefore, the antioxidant activity of $\mathrm{RBCH}$ was measured in linoleic acid system and compared with those of tocopherol and BHT. As shown in Fig. 5d, the control had the highest absorbance value in this experiment, indicating the highest degree of oxidation among the samples after an 8-day incubation, whereas RBCH markedly retarded lipid peroxidation in the linoleic acid emulsion system. The strongest inhibition activity of linoleic acid peroxidation was about $80 \%$ which was too close to tocopherol, while it was much lower than that of synthetic antioxidant BHT. This result is similar to those of wheat germ protein hydrolysate [51] and BNH-P7 derived from blue mussel protein [20]. Though the synthetic antioxidants like BHT exhibit higher potent on inhibition of lipid peroxidation, they are restricted at higher concentrations for their toxicological factors [52]. In other words, $\mathrm{RBCH}$ with excellent antioxidant activity could be used at high concentration without side effects, and simultaneously impart desirable nutritional and functional properties to the final products. The strong inhibition potency of $\mathrm{RBCH}$ against linoleic acid might be attributed to enzymatic hydrolysis, which might give rise to both the release of antioxidant sequences and the exposition of previously hidden amino acid residues and side chains with antioxidant activity.

\section{Conclusion}

The combination of neutrase and flavourzyme exhibited synergetic effects on the hydrolysis of protein derived from duck blood. The optimum conditions for degradation were temperature $51{ }^{\circ} \mathrm{C}$, substrate concentration $14 \%(w / v), \mathrm{pH} 7.0$, and time $7.5 \mathrm{~h}$. Hydrolysate prepared under the optimal conditions was characterized by having abundant small peptides $(<3 \mathrm{kDa}, 68.14 \%)$ and high essential amino acid contents to fulfill human requirements. 
The spray-dried hydrolysate had enhanced solubility, higher emulsifying and foaming properties. $\mathrm{RBCH}$ also showed excellent DPPH radical-scavenging activity, reducing power and metal chelating activity to retard the lipid peroxidation. Therefore, a process for bioconversion of poultry waste was established, and the obtained peptide hydrolysate had the potential to be applied in food systems as a natural additive with good functional properties and antioxidant activity.

\section{Additional file}

Additional file 1: Table S1. Analysis of variance for the regression model of $\mathrm{DH}$. (DOCX $34 \mathrm{~kb})$

\section{Abbreviations}

BHT: Butylated hydroxyltoluene; CCD: Central composite design; DH: Degree of hydrolysis; DPPH: 2,2-diphenyl- 1-picrylhydrazyl; EAl: Emulsifying activity index; ESI: Emulsion stability index; RBC: Red blood cell; RBCH: Red blood cell hydrolysate; ROS: Reactive oxygen species; RSM: Response surface methodology

\section{Acknowledgements}

The authors would like to thank and acknowledge the help of Yangyuan Biological Engineering Co., Beijing, China.

\section{Funding}

This research was supported by the grant from the Agriculture Science Technology Achievement Transformation Fund of China (2011GB2A000009) and Natural Science Foundation (No. 31272476).

\section{Availability of data and materials}

The datasets used and analyzed during the current study available from the corresponding author on reasonable request.

\section{Authors' contributions}

JZ wrote the manuscript and carried out all experiments. TS and XW performed the experiment of optimization. YH helped design the experiment by using response surface method and analyze the results. $\mathrm{CH}$ assisted in manuscript revision. RZ designed the study and assisted in manuscript revision. All authors read and approved the final manuscript.

\section{Ethics approval}

The protocol reviewed and approved by the Animal Care and Use Committee of Beijing Municipal Bureau of Agriculture, Beijing, People's Republic of China. All procedures were carried out in strict accordance with the recommendations in the Guide for Guidelines for Experimental Animals of the Ministry of Science and Technology (Beijing, China), and all efforts were made to minimize any discomfort during blood collection.

\section{Consent for publication}

Not applicable.

\section{Competing interests}

The authors declare that they have no competing interests.

\section{Publisher's Note}

Springer Nature remains neutral with regard to jurisdictional claims in published maps and institutional affiliations.

\section{Author details}

'State Key Laboratory of Animal Nutrition, College of Animal Science and Technology, China Agricultural University, Beijing 100193, China. 2Department of Computer Science, College of Information and Electrical Engineering, China Agricultural University, Beijing 100083, China.
Received: 30 October 2017 Accepted: 1 October 2018

Published online: 20 October 2018

\section{References}

1. Parés D, Toldrà M, Saguer E, Carretero C. Scale-up of the process to obtain functional ingredients based in plasma protein concentrates from porcine blood. Meat Sci. 2014:96(1):304-10.

2. Man-Jin In HJC, Nam-Soon O. Process development for heme-enriched peptide by enzymatic hydrolysis of hemoglobin. Bioresour Technol. 2002; 84(1):63-8.

3. Woiciechowski AL, Karp SG, Sobral K, de Carvalho JC, Letti LAJ, Soccol VT, Soccol CR. Pretreatment strategies to enhance value addition of agroindustrial wastes. In: Biotransformation of Waste Biomass into High Value Biochemicals. New York: Springer. 2014. p. 29-49.

4. Kristinsson HG, Rasco BA. Fish protein hydrolysates: production, biochemical, and functional properties. CRC Crit Rev Food Sci Nutr. 2000;40(1):43.

5. Adler-Nissen J. Enzymic hydrolysis of food proteins. London: Elsevier applied science publishers. 1986. p. 110-124.

6. Ovissipour M, Kenari AA, Motamedzadegan A, Nazari RM. Optimization of enzymatic hydrolysis of visceral waste proteins of yellowfin tuna (Thunnus albacares). Food Bioprocess Technol. 2012;5(2):696-705.

7. Rawdkuen S, Sai-Ut S, Benjakul S. Optimizing the Tyrosinase inhibitory and antioxidant activity of mango seed kernels with a response surface methodology. Food Anal Methods. 2016:9(11):3032-43.

8. Liu TX, Wang J, Zhao MM. In vitro haem solubility of red cell fraction of porcine blood under various treatments. Int J Food Sci Technol. 2010:45(4): 719-25.

9. Yuliana $M$, Truong $C T$, Huynh $L H$, Ho QP, Ju Y-H. Isolation and characterization of protein isolated from defatted cashew nut shell: influence of $\mathrm{pH}$ and $\mathrm{NaCl}$ on solubility and functional properties. LWT- Food Sci Technol. 2014:55(2):621-6.

10. Klompong V, Benjakul S, Kantachote D, Shahidi F. Antioxidative activity and functional properties of protein hydrolysate of yellow stripe trevally (Selaroides leptolepis) as influenced by the degree of hydrolysis and enzyme type. Food Chem. 2007:102(4):1317-27.

11. Gbogouri G, Linder M, Fanni J, Parmentier M. Influence of hydrolysis degree on the functional properties of salmon byproducts hydrolysates. J Food Sci. 2004;69(8):C615-22.

12. Mendis E, Rajapakse N, Kim S-K. Antioxidant properties of a radicalscavenging peptide purified from enzymatically prepared fish skin gelatin hydrolysate. J Agr Food Chem. 2005;53(3):581-7.

13. Liu Q, Kong B, Xiong YL, Xia X. Antioxidant activity and functional properties of porcine plasma protein hydrolysate as influenced by the degree of hydrolysis. Food Chem. 2010;118(2):403-10.

14. Zheng Z, Huang Y, Wu R, Zhao L, Wang C, Zhang R. Response surface optimization of enzymatic hydrolysis of duck blood corpuscle using commercial proteases. Poult Sci. 2014; 93(10):2641-50.

15. Nielsen PM, Petersen D, Dambmann C. Improved method for determining food protein degree of hydrolysis. J Food Sci. 2001;66(5):642-6.

16. Suppavorasatit I, De Mejia EG, Cadwallader KR. Optimization of the enzymatic deamidation of soy protein by protein-glutaminase and its effect on the functional properties of the protein. J Agric Food Chem. 2011;59(21): $11621-8$

17. Kato A, Fugishing T, Matsudomi N, Kobashi K. Determination of foaming properties of proteins by conductivity measurement. J Food Sci. 1983:48:62-5

18. Sun YP, Chou CC, Yu RC. Antioxidant activity of lactic-fermented Chinese cabbage. Food Chem. 2009;115(3):912-7.

19. Taheri A, Sabeena Farvin KH, Jacobsen C, Baron CP. Antioxidant activities and functional properties of protein and peptide fractions isolated from salted herring brine. Food Chem. 2014;142:318-26.

20. Wang B, Li L, Chi C-F, Ma J-H, Luo H-Y, Y-f X. Purification and characterisation of a novel antioxidant peptide derived from blue mussel (Mytilus edulis) protein hydrolysate. Food Chem. 2013;138(2):1713-9.

21. Peričin D, Radulović-Popović L, Vaštag Ž, Mađarev-Popović S, Trivić S. Enzymatic hydrolysis of protein isolate from hull-less pumpkin oil cake: application of response surface methodology. Food Chem. 2009;115(2): 753-7.

22. Nilsang S, Lertsiri S, Suphantharika M, Assavanig A. Optimization of enzymatic hydrolysis of fish soluble concentrate by commercial proteases. Food Eng. 2005;70(4):571-8. 
23. Imm J, Lee C. Production of seafood flavor from red hake (Urophycis chuss) by enzymatic hydrolysis. J Agric Food Chem. 1999;47(6):2360-6.

24. Vijayalakshmi M, Lemieux L, Amiot J. High performance size exclusion liquid chromatography of small molecular weight peptides from protein hydrolysates using methanol as a mobile phase additive. J Liq Chromatogr Relat Technol. 1986;9(16):3559-76.

25. Sarmadi BH, Ismail A. Antioxidative peptides from food proteins: a review. Peptides. 2010;31(10):1949-56.

26. He H, Chen X, Sun C, Zhang Y, Gao P. Preparation and functional evaluation of oligopeptide-enriched hydrolysate from shrimp (Acetes chinensis) treated with crude protease from Bacillus sp. SM98011. Bioresour Technol. 2006; 97(3):385-90.

27. FAO/WHO: Protein quality evaluation; 1991.

28. Bhaskar N, Mahendrakar N. Protein hydrolysate from visceral waste proteins of Catla (Catla catla): optimization of hydrolysis conditions for a commercial neutral protease. Bioresour Technol. 2008;99(10):4105-11.

29. Ovissipour M, Abedian A, Motamedzadegan A, Rasco B, Safari R, Shahiri H. The effect of enzymatic hydrolysis time and temperature on the properties of protein hydrolysates from Persian sturgeon (Acipenser persicus) viscera. Food Chem. 2009;115(1):238-42.

30. FAO/WHO: Energy and protein requirements. WHO Tech Rep Ser 1985.

31. Naqash SY, Nazeer R. Antioxidant and functional properties of protein hydrolysates from pink perch (Nemipterus japonicus) muscle. J Food Sci Technol. 2013;50(5):972-8.

32. Giménez B, Alemán A, Montero P, Gómez-Guillén M. Antioxidant and functional properties of gelatin hydrolysates obtained from skin of sole and squid. Food Chem. 2009;114(3):976-83.

33. Chalamaiah M, Jyothirmayi T, Diwan PV, Kumar BD. Antioxidant activity and functional properties of enzymatic protein hydrolysates from common carp (Cyprinus carpio) roe (egg). J Food Sci Technol. 2015;52(9):5817-25.

34. Thiansilakul Y, Benjakul S, Shahidi F. Compositions, functional properties and antioxidative activity of protein hydrolysates prepared from round scad (Decapterus maruadsi). Food Chem. 2007;103(4):1385-94.

35. Liu Y, Li X, Chen Z, Yu J, Wang F, Wang J. Characterization of structural and functional properties of fish protein hydrolysates from surimi processing byproducts. Food Chem. 2014;151:459-65.

36. Chobert JM, Bertrand-Harb C, Nicolas MG. Solubility and emulsifying properties of caseins and whey proteins modified enzymically by trypsin. J Agric Food Chem. 1988;36(5):883-92.

37. Kristinsson HG, Rasco BA. Biochemical and functional properties of Atlantic salmon (Salmo salar) muscle proteins hydrolyzed with various alkaline proteases. J Agric Food Chem. 2000;48(3):657-66.

38. Lawal O, Adebowale K, Adebowale Y. Functional properties of native and chemically modified protein concentrates from Bambarra groundnut. Food Res Int. 2007:40(8):1003-11.

39. Wang B, Li Z-R, Chi C-F, Zhang Q-H, Luo H-Y. Preparation and evaluation of antioxidant peptides from ethanol-soluble proteins hydrolysate of Sphyrna lewini muscle. Peptides. 2012;36(2):240-50

40. Chi C-F, Wang B, Wang Y-M, Zhang B, Deng S-G. Isolation and characterization of three antioxidant peptides from protein hydrolysate of bluefin leatherjacket (Navodon septentrionalis) heads. J Funct Foods. 2015;12:1-10.

41. Dong S, Zeng M, Wang D, Liu Z, Zhao Y, Yang H. Antioxidant and biochemical properties of protein hydrolysates prepared from silver carp (Hypophthalmichthys molitrix). Food Chem. 2008;107(4):1485-93.

42. Saiga A, Tanabe S, Nishimura T. Antioxidant activity of peptides obtained from porcine myofibrillar proteins by protease treatment. J Agric Food Chem. 2003:51(12):3661-7.

43. He R, Girgih AT, Malomo SA, Ju X, Aluko RE. Antioxidant activities of enzymatic rapeseed protein hydrolysates and the membrane ultrafiltration fractions. J Funct Foods. 2013;5(1):219-27.

44. Girgih AT, He R, Hasan FM, Udenigwe CC, Gill TA, Aluko RE. Evaluation of the in vitro antioxidant properties of a cod (Gadus morhua) protein hydrolysate and peptide fractions. Food Chem. 2015;173:652-9.

45. Xie Z, Huang J, Xu X, Jin Z. Antioxidant activity of peptides isolated from alfalfa leaf protein hydrolysate. Food Chem. 2008;111(2):370-6.

46. Zhang L, Li J, Zhou K. Chelating and radical scavenging activities of soy protein hydrolysates prepared from microbial proteases and their effect on meat lipid peroxidation. Bioresour Technol. 2010;101(7):2084-9.

47. Samaranayaka AG, Li-Chan EC. Autolysis-assisted production of fish protein hydrolysates with antioxidant properties from Pacific hake (Merluccius productus). Food Chem. 2008;107(2):768-76.
48. Rajapakse N, Mendis E, Jung W-K, Je J-Y, Kim S-K. Purification of a radical scavenging peptide from fermented mussel sauce and its antioxidant properties. Food Res Int. 2005;38(2):175-82.

49. Thiansilakul Y, Benjakul S, Shahidi F. Antioxidative activity of protein hydrolysate from round scad muscle using alcalase and flavourzyme. J Food Biochem. 2007:31(2):266-87.

50. You L, Zhao M, Regenstein JM, Ren J. Changes in the antioxidant activity of loach (Misgurnus anguillicaudatus) protein hydrolysates during a simulated gastrointestinal digestion. Food Chem. 2010;120(3):810-6.

51. Zhu K, Zhou H, Qian H. Antioxidant and free radical-scavenging activities of wheat germ protein hydrolysates (WGPH) prepared with alcalase. Process Biochem. 2006;41(6):1296-302.

52. Li Y, Jiang B, Zhang T, Mu W, Liu J. Antioxidant and free radical-scavenging activities of chickpea protein hydrolysate (CPH). Food Chem. 2008;106(2): $444-50$
Ready to submit your research? Choose BMC and benefit from:

- fast, convenient online submission

- thorough peer review by experienced researchers in your field

- rapid publication on acceptance

- support for research data, including large and complex data types

- gold Open Access which fosters wider collaboration and increased citations

- maximum visibility for your research: over $100 \mathrm{M}$ website views per year

At BMC, research is always in progress.

Learn more biomedcentral.com/submissions 